\title{
Factors Influencing Tax Evasion of Businesses: The Case of Albania
}

\author{
Meleq Hoxhaj \\ MSc. Economics, Researcher Scholar, Albanian \\ Customs Administration, Albania \\ Erjus Kamolli \\ MSc. Finance, Researcher Scholar, Albanian \\ Customs Administration, Albania
}

\section{Abstract}

The aim of this paper is to analyse factors affecting tax evasion of business es in Albania. Business tax evasion is a phenomenon that has to do with people trying not to pay the level of taxes they owe, as such it is understood to be as old a phenomenon as taxation. Factors affecting tax evasion vary from country to country, although they can be grouped into economic, psychological and social factors. Nowadays tax evasion has become an increasingly worrying phenomenon so it is important to analyse the factors that make people have an unethical attitude towards taxes, in order to identify the policies needed to mitigate this phenomenon. In our paper we initially made a description of this phenomenon and the main influencing factors. Following the data collected through a questionnaire in some businesses in Albania we have made an analysis to find the relationship between the tendency for business evasion and demographic factors such as age and gender of the person as well as factors such as the period of operation of the firm in the market, the size of the firm and the perception of the level of fines. The results show that young people, men, new firms in the market, large firms and when the perception of the level of fines is low there is a greater tendency for evasion.

Keywords: tax evasion, taxation, Albania, tax avoidance

JEL Classification: H26, H25, H71

\section{Introduction}

This paper aims to make a more detailed presentation of tax evasion of businesses in Albania, its causes, characteristics and consequences. Fiscal evasion of businesses is a new phenomenon, from the moment that businesses in their form have started to pay taxes, people have found ways to avoid paying these taxes and to evade. The idea 
of this paper came that this phenomenon is very widespread in Albania, a very problematic phenomenon and at the same time little discussed and analysed. It is necessary to identify the extent to which this phenomenon is and what are the reasons that cause businesses to commit tax evasion, to give the necessary suggestions. To make a more complete analysis, a study has been done, completing a questionnaire with business representatives to see their opinion on the causes of evasion in Albania and to understand the characteristics of this phenomenon. To gain a better understanding of tax evasion in Albania, it is important to examine the structure of enterprises as well as the taxation system. In the last part of the paper we have analysed the primary data collected with questionnaires in various businesses, for their opinion on the tax system, business evasion and their evasive tendencies.

\section{Literature review}

Several writers and academics have developed their own working definition of tax avoidance. Tax evasion is described as deliberate and criminal non-compliance with tax obligations Bhuiyan (2012). Tax avoidance is an attempt to decrease the amount of taxes owed, by taking advantages of the weaknesses, loopholes or ambiguities in the tax legislation (GIZ, 2010, p.9). Tax avoidance, according to OECD is a tax-saving plan in which a taxpayer arranges his affairs in order to decrease his tax burden. Tax avoidance is the deliberate act of lowering one's taxes using legal ways Bhuiyan (2012). GIZ (2010) groups factors of tax evasion in four groups: low tax morale, high compliance costs, insufficient tax collection capacity, and inefficiency in tax collection. Among the most significant in the first category are: tax system fairness, low transparency and accountability of public institutions, low quality public services, corruption, absence of rule of law, and weak fiscal jurisdiction; the questions that might be asked as a justification for not paying taxes could be: why pay taxes if they are stolen by corrupted government officials, if government is not transparent to public or government doesn't deliver good services for the public, or is the tax system regarded to be unfair?

Literature about tax evasion is broad, but researchers have not yet reached at a unique conclusion about the set of common tax evasion factors, Marandu, E.E., et al (2014). Kanybek, Nur-Tegin, (2008) analyzed data from 4538 firms from 23 countries and found that together with corruption, high tax rates, low discovery likelihood, low faith in government, high compliance costs tend to stimulate tax evasion. Oz Yalama, Gumus, (2013), Feld, Torgler and Dong (2008) used factor analysis and regression techniques and found that major determinants of tax evasion are high tax rates, heavy tax burden, income level, tax audits, tax morale, education and bureaucracy. Bismark identifies reduction of tax rates and conferring penalties on tax payers as major factors to reducing tax evasion. Crane and Nourzad, (1986) also say that penalty rates seem to negatively effect tax evasion. Another study done by Seidu., et al. (2015) examined the reasons of tax delinquency among Small and Medium Enterprises (SMEs) in Ghana's Tamale Metropolis. They found that tax evasion is 
caused by low level of tax education among SMEs, nature of business and multiple taxation.

\section{Information about Albania}

Albania, with a population of 2,829,741 people, is a small state ${ }^{1}$, the economy based until recent years mainly on remittances and dominated mainly by small family businesses in the services and trade sector (166,386 enterprises in total in 20202). Until the 90s, the Albanian economy was a centralized economy and there was no free market and private property, with the advent of capitalism, the first businesses began to be created. Currently Albania is a market economy with a large number of mostly family businesses. In the figure below is presented value added in 2019 in total from enterprises in Albania is $582083 \mathrm{ml} \mathrm{ALL}^{3}$, the largest contributor is the services producers enterprises with a value of $339,457 \mathrm{ml}$ ALL or about $58.3 \%$ of total and contributed by +3.6 point percent in annual turnover.

Producers of goods, manufacturing, power, gas, water supply and construction enterprises make up nearly 41.7 percent of total turnover realized.

Figure 1 Value added of Albanian Enterprise in 2019 (ml ALL)

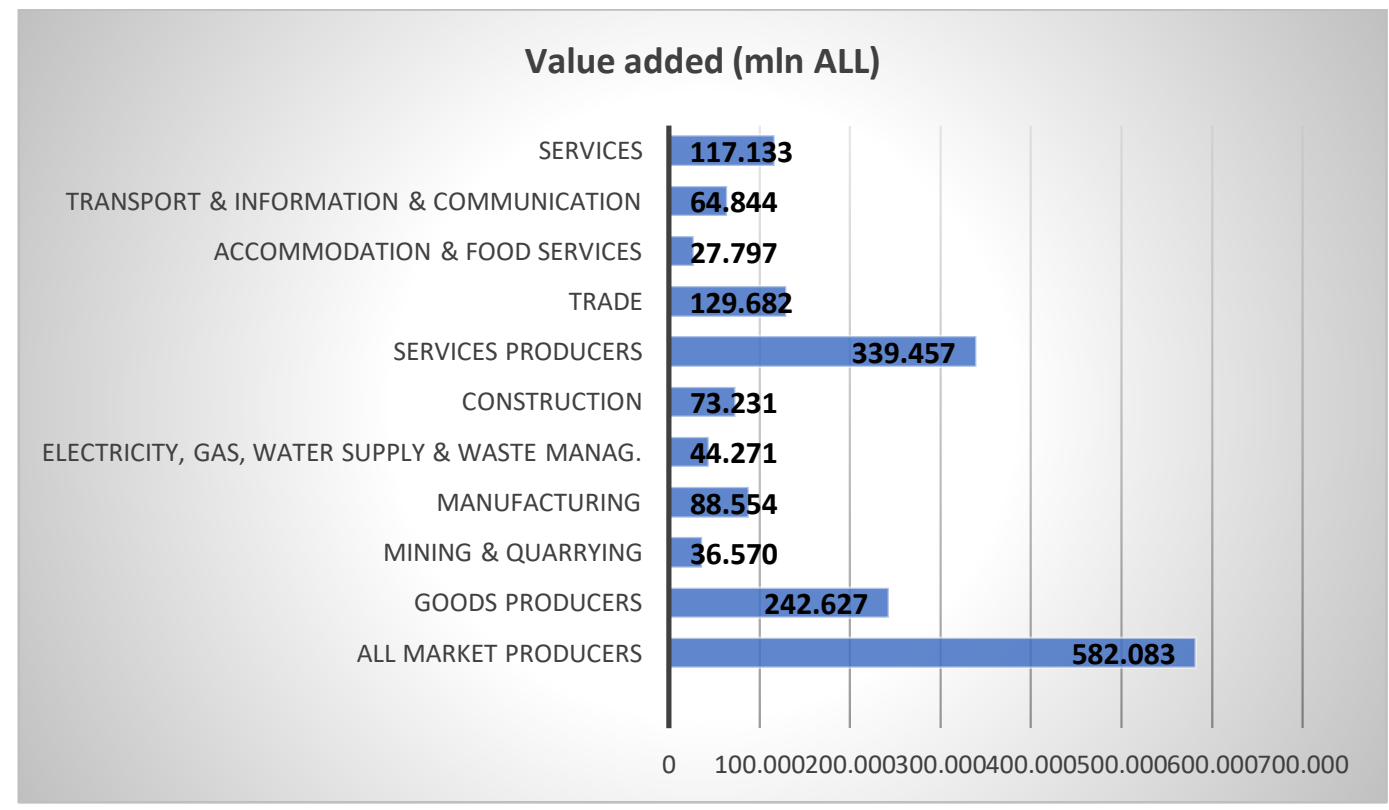

Source: http://databaza.instat.gov.al/pxweb/sq/DST/START_EE/

In figure below is presented number of enterprises in 2019 in total and number in each sector of economy. We see that in 2019 in Albania are 104,090 enterprises in

\footnotetext{
${ }^{1}$ http://www.instat.gov.al/al/statistika/t\%C3\%AB-dh\%C3\%ABna-ky\%C3\%A7e/

2 http://www.instat.gov.al/al/statistika/t\%C3\%AB-dh\%C3\%ABna-ky\%C3\%A7e/

3 http://databaza.instat.gov.al/pxweb/sq/DST/START_EE/
} 
total which decrease by $3.1 \%$ compared to $2018,90,870$ or $87.2 \%$ of which are services producers enterprises and only 13,220 or $12.8 \%$ are good producers enterprises. Enterprises operating in trade sector comprise $40.0 \%{ }^{1}$. In this group of enterprises, trade of vehicles, wholesale and retail trade has the largest share of services producers. In trade sector operates $40.02 \%$ of enterprises which constitute $22.3 \%$ of total annual turnover realized. Trade sector contributed by +2.7 point percent in the total turnover increase (3.8\%).

Figure 2 Number of Enterprises in Albania in 2019

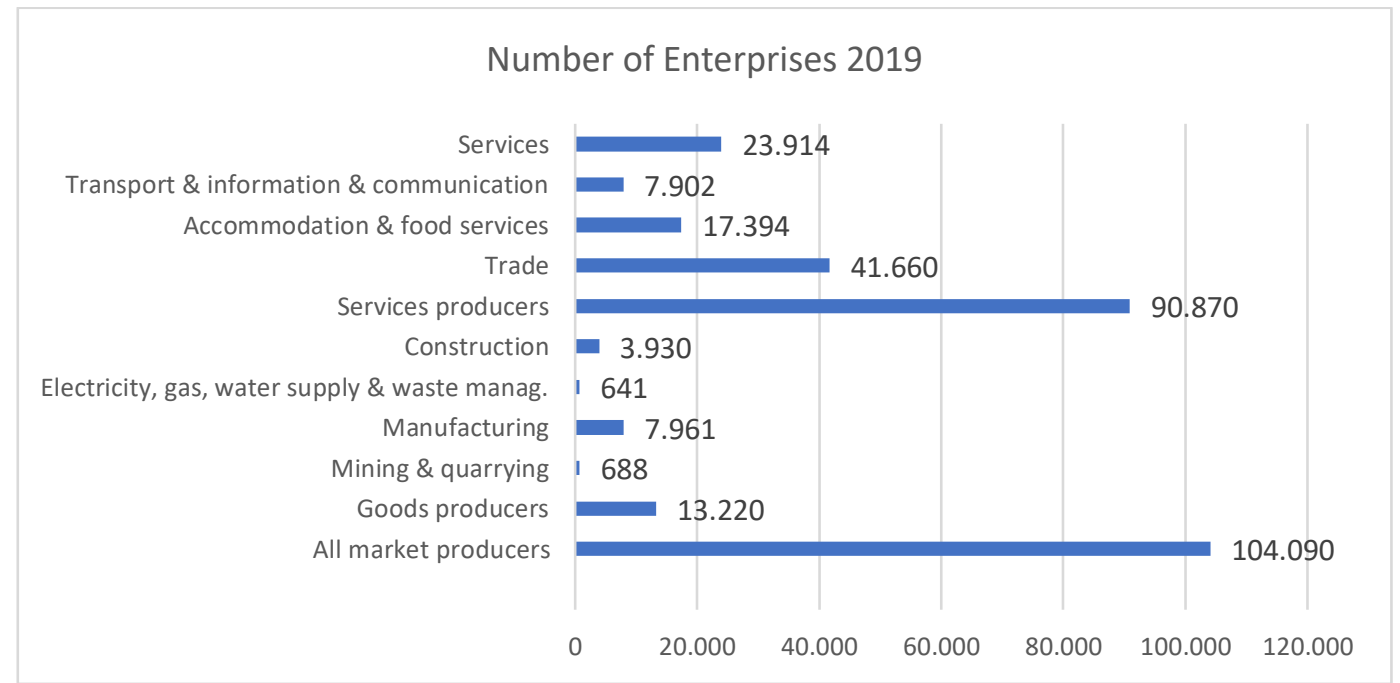

Source: http://databaza.instat.gov.al/pxweb/sq/DST/START_EE/

If we see number of enterprises by size (number of persons employed) we can say that 96,924 enterprises (93.1\%) are micro (1-9 employed) that show again that economy of Albania is dominated mostly from micro family enterprises.

${ }^{1}$ http://mail.instat.gov.al/media/8365/materiali-shkrimor-asn-2019_11022021_last.pdf 
Figure 3 Number of Enterprises for each category (small, micro, big) in Albania in 2019

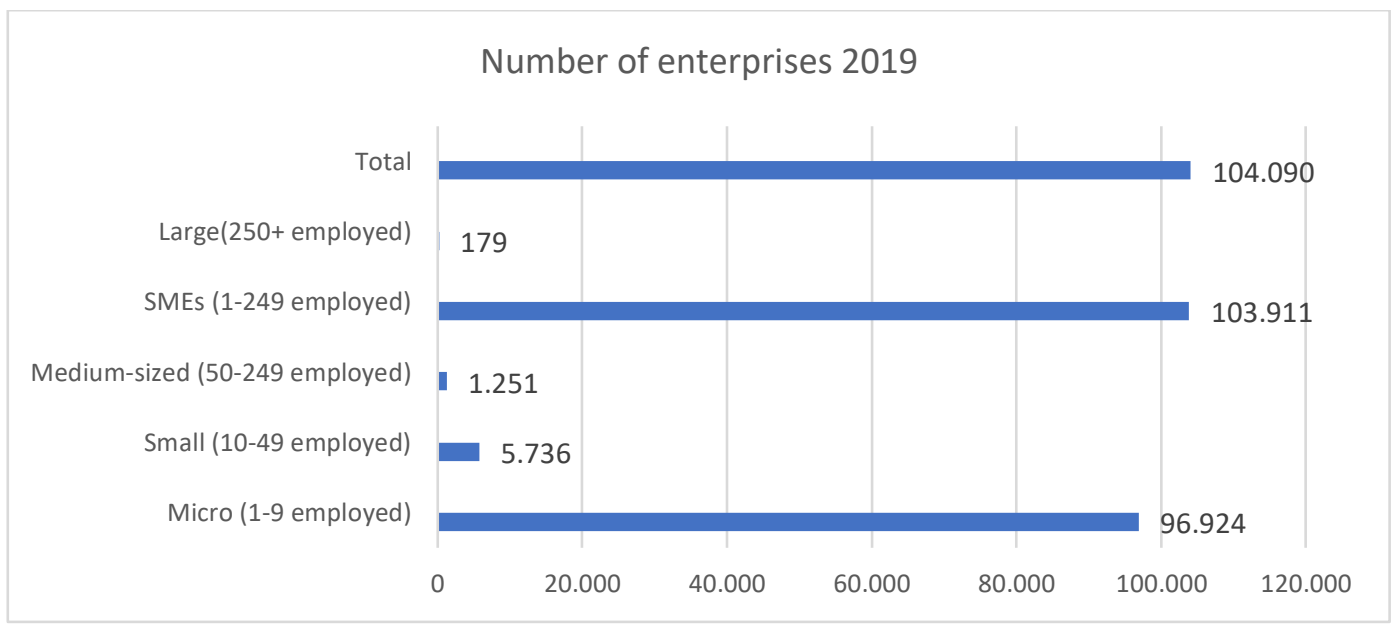

Source: http://databaza.instat.gov.al/pxweb/sq/DST/START_EE/

In this figure is presented number of enterprises by economic activity and ownership. Albania own 80,272 or $97.8 \%$ of enterprises in services sectors and 14,425 or $93.6 \%$ of enterprises in producers of good sector. In total 94,697 or $97.1 \%$ of enterprises are own by Albanian, 1,618 or $1.6 \%$ are own by Foreigner and 1,121 or $1.3 \%$ are own by Albanian and Foreign shareholders.

Figure 4 Number of Enterprises by activity and ownership in 2019 in Albania

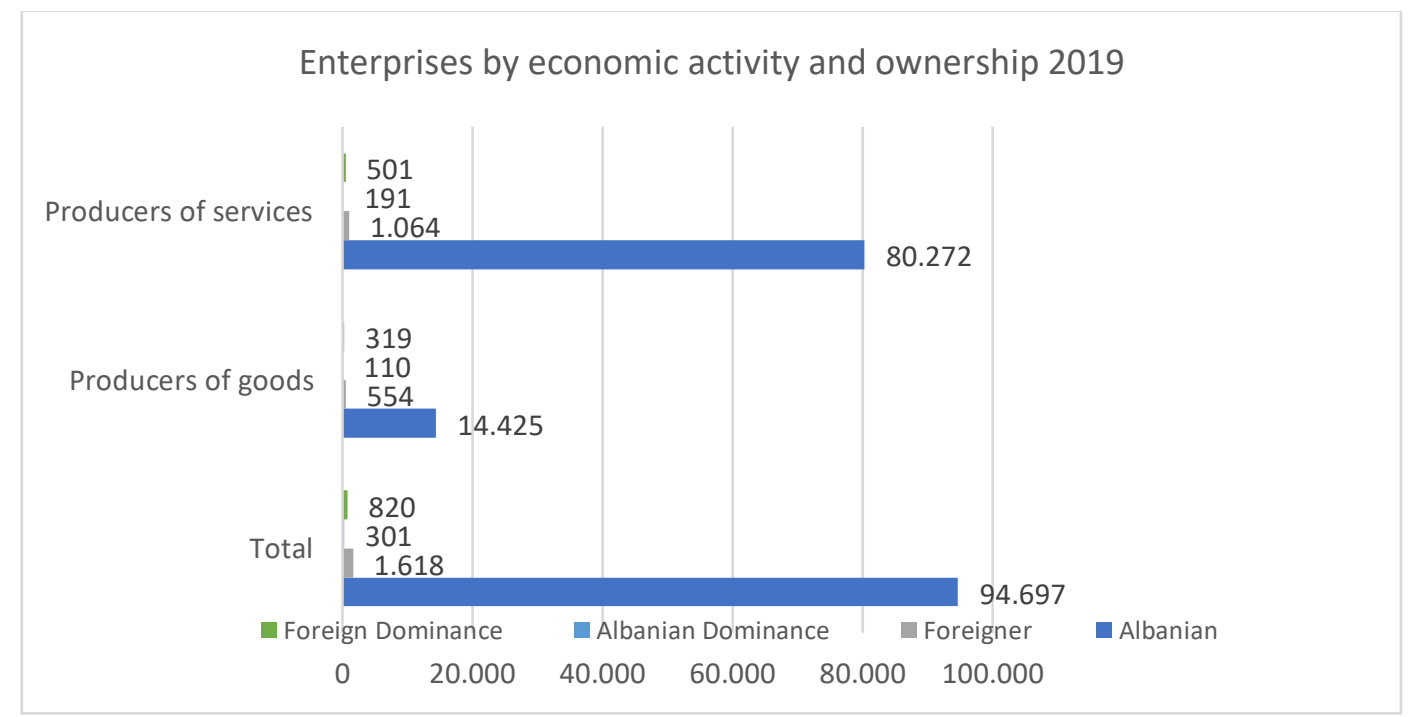

Source: http://databaza.instat.gov.al/pxweb/sq/DST/START_EE/ 
It is necessary to emphasize that the data obtained to analyse the structure of businesses as above are from 2019 for two reasons, the first reason is that the data for 2020 are still not fully published and the second reason because there are was a year affected by the pandemic and would not accurately show the normal progress and situation as it was until 2019. Secondly it is worth noting that as we see from the above figures businesses in Albania are mainly small family businesses in trade and services sector. This finding will be useful for us to better understand the situation of tax evasion in Albania by looking at evasive behaviours according to relevant factors.

Table 1 Albanian tax rates for the main categories

\begin{tabular}{|c|c|}
\hline Type of Tax & Tax rate \\
\hline Profit Tax & \\
\hline $0 \%$ & For revenue up to $14,000,000 \mathrm{ALL}$ \\
\hline $5 \%$ & $\begin{array}{l}\text { For legal entities, to exercise their activity for e-software. } \\
\text { 2. For legal entities, to develop economic activities according to law no. 38/2012, "On } \\
\text { the agricultural ability society". } \\
\text { For legal entities, to exercise economic activity in the automotive industry. }\end{array}$ \\
\hline $15 \%$ & For revenue over $14,000,000 \mathrm{ALL}$ \\
\hline Dividend Tax & \\
\hline $8 \%$ & On the profit distributed to the owners \\
\hline Personal Income Tax & \\
\hline $0 \%$ & for monthly income up to $30,000 \mathrm{ALL}$ \\
\hline $13 \%$ & for monthly income over 30,000 ALL up to $150,000 \mathrm{ALL}$ \\
\hline $23 \%$ & for monthly income over $150,000 \mathrm{ALL}$ \\
\hline Source Tax & \\
\hline $15 \%$ & for rent of the building where the activity of business is performed \\
\hline Vat Tax & \\
\hline $0 \%$ & $\begin{array}{l}\text { Some specific goods or services } \\
\text { Import of live calves and lambs for fattening } \\
\text { Supply and import of gold for investments } \\
\text { Supply of postal service } \\
\text { Supply of medicines } \\
\text { Supply of human organs, blood and milk } \\
\text { Some other category }\end{array}$ \\
\hline $6 \%$ & for price of services for accommodation structure \\
\hline $20 \%$ & for price of almost all goods or services \\
\hline
\end{tabular}

Source: Tax procedures in the Republic of Albania Law No. 9920/2008.

As we can see from the above we can say that the tax system in Albania is generally simple and not overly categorized. Also tax burden in Albania is low compared to the region. This is useful for us to better understand what factors motivate businesses to commit tax evasion.

The state of tax evasion in Albania is difficult to assess, owing to a lack of precise statistics and reports from the competent agencies. It is challenging to collect the necessary data due to the increasing bureaucracy and huge number of money transactions. The International Monetary Fund considers the VAT mismatch caused 
by efficiency to be an approximation to tax evasion. They estimate a possible VAT compliance gap of 34-39 percent, which is somewhat higher than the regional norm and has been increasing since 2008. Albania's black economy is projected to account for 33 percent of GDP in 2014, which is much higher than the European average of 18.6 percent.

\section{Methodology}

The primary goal of this paper is to identify the elements that influence company tax avoidance in Albania. All respondents are responsible for tax of company that they are working. The auxiliary hypotheses are as below:

H1. Gender affects tax evasion. Women have more ethical behaviour in terms of tax evasion.

H2. Age impacts tax evasion behaviour. Older individuals are more ethical in terms of tax payments.

H3. The period of operation of a firm in the market affects the tendency for tax evasion. A firm that has been operating in the market for many years has a low tendency for tax evasion.

H4. The size of the firm influences the tendency for tax evasion. Larger firms have a greater tendency to avoid taxes and commit tax evasion.

H5. The level of fines affects the tendency of businesses for tax evasion. A high level and heavy fines make businesses have a more ethical behaviour regarding the payment of taxes.

H6. The level of corruption in the administration affects the tendency for tax evasion. A corrupt administration leads to tax evasion by businesses.

H7. Unfair competition affects tax evasion. Unfair competition at high levels encourages businesses to avoid paying taxes and make tax evasion.

H8. The constant change of rules and norms affects the tendency of businesses for tax evasion. The more frequent these changes, the higher the tendency of businesses to avoid paying taxes and to evade.

The questionnaire is completed in some cities and villages of the country (Tirana, Fier and some respective villages) during January 2021. We created survey in google forms and by sharing link to some devices, completed them going in random businesses. The respondents selected fulfilled the requirement for receiving answers from businesses in different sectors, different size and different age, gender and education levels of respondents.

The survey included 9 demographic questions, 10 questions about opinion for tax system in Albania, 6 questions about tendency for tax evasion and 7 questions about factors that effect decision of businesses for tax evasion. Several questions of survey 
are original created by us and others have been used in prior studies about tax evasion. Some of questions used before are "Corruption of the tax administration", "I am confident that the government is fighting and punishing people who avoid tax evasion" (Masarirambi 2013), "Your education", "Sector where the company operates", "How many years has the company been operating in the market?", "Tasks you perform in the company?", "How is your business classified according to annual turnover", "How is your business classified according to the number of employees?" (Tusubira 2018). Responses are on Linear scale ranking from $1=$ Totally Disagree, $2=$ Disagree, $3=$ Neutral, 4=Agree, $5=$ Totally Agree. The survey is presented in Appendix.

\section{Results}

Table 2 Frequency of demographic characteristics

\begin{tabular}{|c|c|c|c|}
\hline Demographic Attribute & Sample Frame & Frequencies & $\%$ \\
\hline \multirow[t]{4}{*}{ Age } & $18-30$ & 27 & 11.06 \\
\hline & $31-45$ & 113 & 46.31 \\
\hline & $46-60$ & 92 & 37.7 \\
\hline & Over 60 & 12 & 4.91 \\
\hline \multirow[t]{2}{*}{ Gender } & Male & 150 & 61.48 \\
\hline & Female & 94 & 38.52 \\
\hline \multirow[t]{4}{*}{ Education Level } & Primary & 7 & 2.87 \\
\hline & Secondary & 138 & 56.56 \\
\hline & University & 88 & 36.06 \\
\hline & Postgraduate & 11 & 4.51 \\
\hline \multirow[t]{3}{*}{ Urban/Rural } & Urban & 160 & 65.57 \\
\hline & Rural & 26 & 10.66 \\
\hline & Both & 58 & 23.77 \\
\hline \multirow[t]{4}{*}{ Task perform in company } & Owner/Shareholder & 177 & 72.54 \\
\hline & Accountant & 56 & 22.95 \\
\hline & Manager & 5 & 2.05 \\
\hline & Other & 6 & 2.46 \\
\hline \multirow[t]{11}{*}{ Sector of economy } & Services & 69 & 28.28 \\
\hline & Hotels & 3 & 1.23 \\
\hline & Transport & 2 & 0.82 \\
\hline & Production & 17 & 6.97 \\
\hline & Telecommunication & 7 & 2.86 \\
\hline & Trade & 114 & 46.72 \\
\hline & Real Estate & 2 & 0.82 \\
\hline & Construction & 20 & 8.2 \\
\hline & Financial activities & 2 & 0.82 \\
\hline & Free Professional & 5 & 2.05 \\
\hline & Other & 3 & 1.22 \\
\hline
\end{tabular}

Source: Authors' elaboration

\section{H1 is true}

Gender affects tax evasion. Women have more ethical behaviour in terms of tax evasion. 
Questions that: "It is normal for a business to find ways to avoid paying taxes" 3.19\% of woman say that agree and $4.25 \%$ say that totally agree while $10 \%$ of man say that agree and $4.67 \%$ say that totally agree. Also questions that: "We are likely to hide income to pay less taxes" $25.5 \%$ of woman say that agree and $7.44 \%$ say that totally agree while $27.33 \%$ of man say that agree and $11.33 \%$ say that totally agree. Even for questions that "Likely to collaborate with another firm to take action in order to evade taxes" $20.21 \%$ of woman say that agree and $5.31 \%$ say that totally agree, while $24 \%$ of man say that agree and $6 \%$ of man say that totally agree. As we see for each of questions above man are more likely to agree with evasive behaviour.

\section{H2 is true}

Age impacts tax evasion behaviour. Older individuals are more ethical in terms of tax payments.

Questions that: "It is normal for a business to find ways to avoid paying taxes" 7.4\% of people at age $18-30$ say that totally agree, $3.53 \%$ of people $31-45$ years old say that totally agree, $5.43 \%$ of people $46-60$ years old say that totally agree and no one at age over 60 say that agree or totally agree. Also questions that: "We are likely to hide income to pay less taxes" $29.62 \%$ of people at age 18 -30 say that totally agree, $8.85 \%$ of people $31-45$ years old say that totally agree, $6.52 \%$ of people $46-60$ years old say that totally agree and no one at age over 60 say that totally agree. Even for questions that: "Likely to collaborate with another firm to take action in order to evade taxes" $18.52 \%$ of people $18-30$ years old say that totally agree, $5.31 \%$ of people at age 31 45 say that totally agree, $3.26 \%$ of people $46-60$ years old say that totally agree and no one say that totally agree.

\section{H3 is true}

The period of operation of a firm in the market affects the tendency for tax evasion. A firm that has been operating in the market for many years has a low tendency for tax evasion.

Questions that: "We are likely to hide income to pay less taxes" $44.44 \%$ of people in firms with $0-2$ years of operating say that totally agree, $16.13 \%$ of people in firms with $2-5$ years of operating say that totally agree, $8.33 \%$ of people in firms with $6-10$ years of operating say that totally agree and only $6.94 \%$ of people in firms with more than 10 years of operating say that totally agree. Also question that: "Likely to collaborate with another firm to take action in order to evade taxes" $22.22 \%$ of people in firms with $0-2$ years of operating say that totally agree, $6.45 \%$ of people in firms with $2-5$ years of operating say that totally agree, $6.66 \%$ of people in firms with $6-10$ years of operating say that totally agree and only $4.16 \%$ of people in firms with more that 10 years of operating say that totally agree. 


\section{H4 is true}

The size of the firm influences the tendency for tax evasion. Larger firms have a greater tendency to avoid taxes and commit tax evasion.

Questions that: "We are likely to hide income to pay less taxes" no one at firms with turnover below 2 million ALL say that totally agree, $4.38 \%$ of people in firms with turnover 2-8 million ALL say that totally agree, $17.95 \%$ of people in firms with turnover 8-15 million ALL say that totally agree and $18.64 \%$ of people in firms with turnover above 15 million ALL say that totally agree. Also question that: "Likely to collaborate with another firm to take action in order to evade taxes" no one at firms with turnover below 2 million ALL say that totally agree, $2.18 \%$ of people in firms with turnover 2-8 million ALL say that totally agree, $12.82 \%$ of people in firms with turnover 8-15 million ALL say that totally agree and $10.17 \%$ of people in firms with turnover above 15 million ALL say that totally agree.

\section{H5 is true}

The level of fines affects the tendency of businesses for tax evasion. A high level and heavy fines make businesses have a more ethical behaviour regarding the payment of taxes and tax evasion.

From 75 people that totally disagree question that "The consequences of catching for tax evasion (measures, penalties, fines) are not very serious" only 4\% (3 people) say that totally agree for question that "We are likely to hide income to pay less taxes". From 54 people that disagree question that "The consequences of catching for tax evasion (measures, penalties, fines) are not very serious" only 3.7\% (2 people) say that totally agree for question that "We are likely to hide income to pay less taxes". From 40 people that say neutral to question "The consequences of catching for tax evasion (measures, penalties, fines) are not very serious" $12.5 \%$ (5 people) say that totally agree to question "We are likely to hide income to pay less taxes". From 36 people that say agree to question "The consequences of catching for tax evasion (measures, penalties, fines) are not very serious" $16.7 \%$ (6 people) say that totally agree to question "We are likely to hide income to pay less taxes". From 39 people that totally agree that "The consequences of catching for tax evasion (measures, penalties, fines) are not very serious" $20.51 \%$ (8 people) say that totally agree to question "We are likely to hide income to pay less taxes". So we see that people who totally agree that fines and penalties are not so serious tend more to say that agree for hiding income to pay less taxes, showing us that fines and penalties effect behaviour of people regarding tax evasion.

\section{H6 is true}

The level of corruption in the administration affects the tendency for tax evasion. A corrupt administration leads to tax evasion by businesses. 
Only 3.27\% (8 people) answer totally disagree to question that "Corruption of the tax administration affect tax evasion", 4.09\% (10 people) answer disagree, 5.33\% (13 people) answer neutral, $30.73 \%$ (75 people) agree with this question and 56.58\% (138 people) say that totally agree that level of corruption affect tax evasion.

$H 7$ is true

Unfair competition affects tax evasion. Unfair competition at high levels encourages businesses to avoid paying taxes and make tax evasion.

Question that "Unfair competition affect tax evasion" $4.92 \%$ (12 people) say that totally disagree, $6.55 \%$ (16 people) say that disagree, $7.79 \%$ (19 people) say that think neutral, $34.43 \%$ (84 people) say that agree and $46.31 \%$ (113 people) sat that totally agree.

H8 is not true

The constant change of rules and norms does not affect the tendency of businesses for tax evasion.

Question that "Constant changes in the rules and the level of taxes affect tax evasion" $31.1 \%$ (76 people) say that totally disagree, $22.95 \%$ (56 people) say that disagree, $24.18 \%$ (59 people) say that they think neutral, $14.34 \%$ (35 people) say that agree and only $7.38 \%$ (18 people) say that totally agree.

\section{Linear Regressions analysis}

As depended variable we used results of questions "We are likely to hide income to pay less taxes" and independent variable we used results of questions "Age", "Gender" "Size of firms" "Periods of operations" and "Level of fines".

LIKELYTOHIDEINCOME=1.67-0.574*AGE-0.361*GENDER+0.549*SIZEOFFIRMS$0.052 *$ YEARSOFOPERATIONS -0.186 LEVELOFFINES $+\varepsilon$

$\mathbf{R}^{2}=0.736$

$\begin{array}{lllllll}\text { Stand.Dev } & 0.549 & 0.143 & 0.169 & 0.1 & 0.117 & 0.057\end{array}$

$\begin{array}{lllllll}\text { T-Stat } & 3.04 & -2.615 & -0.362 & -5.491 & 0.271 & -2.765\end{array}$

\section{Results of regression analysis}

The linear model is important $F=14.723>3$.

Individual connections turn out to be some important:

$$
\begin{gathered}
|\mathrm{t} 1|=|3.04|>2 \quad|\mathrm{t} 2|=|2.615|>2|\mathrm{t} 3|=|0.362|<2|\mathrm{t} 4|=|5.491|>2 \\
|\mathrm{t} 5|=|0.271|<2|\mathrm{t} 6|=|2.765|>2
\end{gathered}
$$

Explanatory is high is $\mathrm{R}^{2}=0.736$

There is no autocorrelation (Durbin Watson $\mathrm{d}=1.17 \approx 2$ ). 
There is no multicollinearity,

$$
\mathrm{VIF}_{1}=1.746<5 ; \mathrm{VIF}_{2}=1.044<5 ; \mathrm{VIF}_{3}=1.232<5 ; \mathrm{VIF}_{4}=1.519<5 ; \mathrm{VIF}_{5}=1.041<5 \text {. }
$$

There is negative relationship between age evasion. The older are getting the less is tendency of people for evasion.

The negative relationship between gender and evasion it means that female have less tendency for evasion (value 1 for male and 2 for female, 1 is totally disagree with evasion and 5 totally agree so switching from 1 to 2 it means switching in different direction from 5 to 1 direction, that's why it shows negative relationship).

There is a positive relationship between size of firms and evasion, so the large is a firm the higher is tendency for evasion.

There is a negative relationship between years of operations and evasion.

The firms with so many years of operations have less tendency for evasion.

There is a negative relationship between level of fines and evasion.

The higher are fines for evasion the lower is tendency for evasion.

Many studies have found that higher-educated individuals comprehend the meaning of tax responsibilities and the purpose of government programs better, and as a result, they comply more (Schmölders, 1960; Song and Yarbrough, 1978; Spicer and Lundstedt, 1976). Allingham and Sandmo (1972) conclude that increasing the penalty rate promotes compliance behaviour. Friedland, Maital, and Retenberg (1987) investigated tax evasion in 15 different disciplines. According to the study's findings, a large penalty is a more effective deterrent to tax cheating than regular auditing. Noncompliance behaviour differs from individual to person.

The findings on the level of education and tax evasion and tax avoidance are consistent with the findings of Kasipillai et al (2006), Ahmed et al (2007), also Houston and Tran (2001), and Devos (2005), both from Australia, that indicate a significantly positive connection of educational attainment and taxpayers' perception to taxation.

\section{Discussion}

This research is an approach to analyse the tax evasion of businesses in Albania. From our analysis we see that evasion is a complex phenomenon, difficult to measure and influenced at the same time by several factors. Some factors such as the level of fines, unfair competition and corruption of the tax administration can be avoided to reduce the level of evasion, while some other factors such as age and gender are personal factors and can not be avoided. From the linear regression analysis it is noticed that the age of the person and the size of the firm are the factors that influence to the greatest extent the decision for tax evasion.

\section{Conclusions}


Tax evasion is illegal and means actions or omissions made by businesses to not pay taxes or to pay a lower value than the actual liability. The importance of studying tax evasion lies in the effects it brings to the economy, a drop in state budget revenues. The main factors influencing tax evasion are the group into 3 groups called fiscal evasion theories, economic theories that include various economic factors (taxation level, corruption of the tax administration, complex tax system, etc.) as causes of tax evasion, psychological theories that include the behaviour of people and the tendency for evasion and social theories that look at the cause of the behaviours and tendencies that society has for a certain action.

The structure of businesses in Albania shows that mainly in Albania we have small family businesses, in the sector of services. From the analysis of primary data collected through a questionnaire in 244 randomly selected businesses it results that woman have more ethical behaviours than man. Also older people have more ethical behaviour than younger ages. The period of operation of a firm in the market affects the tendency for tax evasion, a firm that has been operating in the market for many years has a low tendency for tax evasion. The size of the firm influences the tendency for tax evasion, larger firms have a greater tendency to avoid taxes and commit tax evasion. The level of fines affects the tendency of businesses for tax evasion, a high level and heavy fines make businesses have a more ethical behaviour regarding the payment of taxes and tax evasion. The level of corruption in the administration affects the tendency for tax evasion, a corrupt administration leads to tax evasion by businesses. Unfair competition affects tax evasion. Unfair competition at high levels encourages businesses to avoid paying taxes and make tax evasion.

The constant change of rules and norms does not seem to have significant effects on the tendency of businesses for tax evasion. The more frequent these changes, does not mean that the tendency of businesses to avoid paying taxes and to evade will be higher.

Further research can be done on Factors Influencing Tax evasion of Businesses in Albania.

It would be especially interesting to study and analyse to what extent tax evasion is in Albania and what is the tendency for evasion in recent years, increasing or decreasing.

\section{Bibliography}

[1] Abdixhiku, L. (2013) Determinants of Business Tax Evasion in Transition Economies (Doctoral dissertation). University of Staffordshire, England. Retrieved from http://eprints.staffs.ac.uk/1962/1/ABDIXHIKU\%20Lumir\%20\%2C\%20The ses\%20Final\%20.pdf

[2] Andoni, M et al (2017). Assessing Determinants of Tax Evasion in Albania - A Multinominal Econometric Approach. 10-12. 
[3] Atawodi, O. W., \& Ojeka, S. A. (2012). Factors that affect tax compliance among SMEs in North Central Nigeria. International Journal of Business and Management, 7(12), 87-96. doi: 10.5539/ijbm.v7n12p87

[4] Awan, A.G, \& Hannan, A (2014) The Determinants of Tax Evasion In PakistanA Case Study of Southern Punjab. International Journal of Development and Economic Sustainability, 2 (4), 50-69.

[5] Bahadur, J. (2018). Tax evasion in Nepal: An Inquiry. Pravaha, 24(1), 83-95. doi: 10.3126/pravaha.v24i1.20228

[6] Bandara, A.G., \& Weerasooriya, W.M.R.B. (2019). A Conceptual Research Paper on Tax Compliance and Its Relationships. International Journal of Business and Management, 14 (10), 134-145. doi: 10.5539/ijbm.v14n10p134

[7] Franzoni, A.L (1998). Tax Evasion and Tax compliance. Encyclopedia of Law and Economics.

[8] Gcabo, R., \& Robinson, Z. (2007). Tax Compliance and Behavioral response in South Africa: An Alternative Investigation. SAJEMS, 10 (3), 357-370.

[9] Gumus, Erdal \& Yalama,G. (2013). Determinants of Tax Evasion Behavior: Empirical Evidence from Survey Data. International Business and Management, 6(2), 15-23. doi: 10.3968/j.ibm.1923842820130602.1085

[10] (INSTAT) Institute of Statistics (Albania) Retrieved from http://databaza.instat.gov.al/pxweb/sq/DST/START_EE/ I

[11] Jayawardane, D. (2015). Psychological Factors affect Tax Compliance- A Review paper. International Journal of Arts and Commerce, 4(6), 134-141.

[12] Joulfaian, D. \& Rider, M. (1998). Differential Taxation and Tax Evasion by Small Business. National Tax Journal, LI(4). 675-687.

[13] Kiri, N. (2016). Factors Affecting Tax Evasion. International Journal of Economics, Commerce and Management, IV(2), 804-811.

[14] Loeprick, J \& Engelschalk, M. (2016). The Taxation of Micro and Small Businesses in Transition Economies: Country Experience of the Introduction of Special Tax Regimes. Journal of Tax Administration, 2(1), 145-197.

[15] Mancharoen, M. (2015) Determinants of Tax Evasion: Perception of SouthernThailand Taxpayers (Master Thesis). University of Utara, Malaysia. Retrieved from http://www.etd.uum.edu.my/5574/2/s815025_02.pdf

[16] Marshal, M.A. (2014) The Impact of Tax Evasion on Revenue Collection Performance in Tanzania A Case study of Tanga Tax Region (Master Thesis). University of Mzumbe, Tanzania. Retrieved from https://www.semanticscholar.org/paper/The-impact-of-tax-evasion-onrevenue-collection-inMarshal/5ac0f0c05ba8fe526ce3ed8fc29b4d307f3348a6

[17] Masarirambi,C (2014) An Investigation into Factors Associated with Tax Evasion in the Zimbabwe Informal Sector: A survey of Mbare Magaba Informal Traders (Master Thesis). Open University of Zimbabwe, Zimbabwe. Retrieved from https://africantheses.org/abstracts/3018-177431 
[18] McGee, R. W., \& Noronha, C. (2008). The Ethics of Tax Evasion: A Comparative Study of Guangzhou (Southern China) and Macau Opinions. Euro Asia Journal of Management, 18(36), 133-152.

[19] Mughal, M. \& Akram, M. (2012). Reasons of tax Avoidance and Tax Evasion: Reflections from Pakistan. Journal of Economics and Behavioral Studies, 4(4), 217-222.

[20] Onu, Diana. \& Oats, Lynne. (2015). The role of social norms in tax compliance: theoretical overview and practical implications. Journal of Tax Administration, 1(1), 113-137.

[21] Salé, M.J., \& Muharremi, O. \& Hoxhaj, M. (2021). Albanian Individual Taxpayers Perceptions and Determinants on Ethical Behavior Regarding Tax Compliance. Business Ethics and Leadership, 5(1), 66-80. doi: http://doi.org/10.21272/bel.5(1).66-80.2021

[22] Tusubira, N. F., (2018) Tax Compliance by the Small and Medium-sized Corporations: A Case of Uganda (Doctoral dissertation). University of Exeter, England. Retrieved from https://ore.exeter.ac.uk/repository/bitstream/handle/10871/33136/Tusu biraF.pdf? sequence $=1$ \&isAllowed $=\mathrm{y}$

\section{Appendix}

\section{Questionnaire}

Your Age $\square$ 18-30 years old $\square$ 31-45 years old $\square$ 46-60 years old $\square$ Over 60 years old

Gender $\square$ Male $\square$ Female

Your Education $\square$ Primary $\square$ Secondary $\square$ University $\square$ Postgraduate

Tasks you perform in the company?

$\square$ Owner / Shareholder

$\square$ Director / Manager

$\square$ Accountant $\square$ Other (Specify)

How many years has the company been operating in the market? $\square 0-2 \quad \square 2-5 \quad \square$ 6-10 $\square$ Over 10 years

\section{Sector where the company operates}

$\square$ Services

$\square$ Production

$\square$ Trade Construction

$\square$ Hotels $\square$ Telecommunications $\square$ Real estate Financial activities

$\square$ Transport $\square$ Free professional $\square$ Other

How is your business classified according to annual turnover 
8 million to 15 million ALL Over 15 million ALL

How is your business classified according to the number of employees?

$\square$ Up to 5 employees

$\square$ From 6 to 20 employees

$\square$ From 21 to 100 employees $\square$ Over 100 employees

Your opinion regarding the assessment of the tax system in the country.

\begin{tabular}{|c|c|c|c|c|c|c|}
\hline & & \multicolumn{3}{|c|}{ Totally Disagree } & \multicolumn{2}{|c|}{ Totally Agree } \\
\hline & Question & 1 & 2 & 3 & 4 & 5 \\
\hline 1 & The VAT rate is appropriate & & & & & \\
\hline 2 & $\begin{array}{l}\text { Advance payment of VAT does not bring problems for } \\
\text { the business }\end{array}$ & & & & & \\
\hline 3 & VAT refund is fair and appropriate & & & & & \\
\hline 4 & The profit tax rate is appropriate & & & & & \\
\hline 5 & The tax rate on personal income is appropriate & & & & & \\
\hline 6 & The progressive income tax system is equitable. & & & & & \\
\hline 7 & $\begin{array}{l}\text { The contribution rate for social and health insurance is } \\
\text { acceptable. }\end{array}$ & & & & & \\
\hline 8 & The taxable base is set at an acceptable level & & & & & \\
\hline 9 & Everyone is treated fairly under the tax system & & & & & \\
\hline 10 & $\begin{array}{l}\text { The tax system is simple to understand and } \\
\text { implement }\end{array}$ & & & & & \\
\hline 11 & $\begin{array}{l}\text { Businesses have good knowledge of how the taxes } \\
\text { and levies collected by them are used by the } \\
\text { government }\end{array}$ & & & & & \\
\hline
\end{tabular}

Your opinion on the tendency of businesses to avoid paying taxes and their trust in the government

\begin{tabular}{|l|l|l|l|l|l|l|}
\hline & \multicolumn{2}{|l|}{ Totally Disagree } & \multicolumn{2}{l|}{ Totally Agree } \\
\hline & Question & 1 & 2 & 3 & 4 & 5 \\
\hline 1 & $\begin{array}{l}\text { Albania has a broad culture of tax evasion and } \\
\text { avoidance. } \\
\text { It is normal for a business to find ways to avoid } \\
\text { paying taxes }\end{array}$ & & & & & \\
\hline 3 & We are likely to hide income to pay less taxes & & & & & \\
\hline 4 & $\begin{array}{l}\text { Likely to collaborate with another firm to take } \\
\text { action in order to evade taxes }\end{array}$ & & & & & \\
\hline 5 & $\begin{array}{l}\text { I am convinced that the government is combating } \\
\text { and prosecuting tax avoidance. }\end{array}$ & & & & & \\
\hline 6 & $\begin{array}{l}\text { Fines and penalty for tax evasion are not very } \\
\text { serious }\end{array}$ & & & & & \\
\hline
\end{tabular}

Your opinion on the factors that influence business decision-making regarding tax evasion 


\begin{tabular}{|l|l|l|l|l|l|l|}
\hline & \multicolumn{2}{|l|}{ Totally Disagree } & \multicolumn{2}{l|}{ Totally Agree } \\
\hline & Questions & 1 & 2 & 3 & 4 & 5 \\
\hline 1 & Low business income & & & & & \\
\hline 2 & Desire for greater profits & & & & & \\
\hline 3 & $\begin{array}{l}\text { Constant changes in the rules and the level of } \\
\text { taxes }\end{array}$ & & & & & \\
\hline 4 & $\begin{array}{l}\text { Corruption of the tax administration } \\
\text { Lack of transparency regarding fiscal changes and } \\
\text { reforms }\end{array}$ & & & & & \\
\hline 6 & High tax rates & & & & & \\
\hline 7 & Unfair competition & & & & & \\
\hline
\end{tabular}

